\title{
David Oliver: The best health system
}

\author{
David Oliver, consultant in geriatrics and acute general medicine
}

Berkshire

Future funding and delivery of UK health services is the subject of unprecedented debate. The media are filled with opinionated talking heads citing selective evidence comparing nations.

Ranking systems isn't easy. Health outcomes are influenced by socioeconomic and lifestyle determinants. Ratings depend on the items picked, the weight given, and the ideological frame. The United Kingdom has four national systems, although they are often unhelpfully aggregated.

Spending per capita or as a percentage of gross domestic product (GDP) is easier to rank than performance. The Organisation for Economic Cooperation and Development (OECD) and the Economist Intelligence Unit (EIU) both place the UK near the bottom among 27 countries ranked for funding as a percentage of GDP. ${ }^{12}$ The EIU showed us to have fewer beds, doctors, and nurses per 1000 population than nearly all.

Lower spending helps efficiency rankings. The Commonwealth Fund table of 11 health systems places us top for cost effectiveness, ${ }^{3}$ even cited by the chancellor's spending review as evidence of the NHS's value for money. ${ }^{4}$ The EIU also praised the UK's efficiency. We are world class for equity of access between rich and poor in those reports and in the Euro Health Consumer Index (EHCI) study. ${ }^{5}$ Bloomberg rated us 17 th of 51 nations for efficiency but 10th for unadjusted healthcare spending versus life expectancy. ${ }^{6}$

What of outcomes? The Commonwealth Fund ranks the UK first overall, using nine indicators, but has been criticised for giving too much weight to surveys and processes. ${ }^{7}$ On its "healthy lives" indicator we reached only ninth place. The OECD put the UK's performance far down the table on five year survival for common cancers, such as breast and bowel, or deaths from myocardial infarction or stroke. The EIU found that our outcomes were "mediocre" overall.

The EHCI placed the UK only 14th in a list of 35 European nations on a scorecard including outcomes, management, and spending. In turn, it has been criticised for an excessive focus on consumer factors around accessibility and choice. ${ }^{8}$

No consistent pattern emerges to link the mix of funding or provision models with quality or value, although dominant payer systems such as the NHS tend to do better on cost and equity than pluralistic insurance.

I'm just one more talking head and I've only touched the surface, but here's my best guess: NHS services were designed to provide free at point of delivery, equitable access to reasonable quality universal services at low cost-not outstanding outcomes, choice, and consumer focus at higher cost.

We could try funding our existing services to average European levels. ${ }^{9}$ UK health spending will be less than 7\% of GDP by $2021 .{ }^{10}$ Behind the media and the lobbying, we find politics, ideology, and over-claiming assertions, not definitive evidence.

Competing interests: See www.bmj.com/about-bmj/freelancecontributors/david-oliver.

Provenance and peer review: Commissioned; not externally peer reviewed.

Organisation for Economic Cooperation and Development. OECD health statistics 2015. Nov 2015. www.oecd.org/els/health-systems/health-data.htm.

2 Economist Intelligence Unit. The NHS: How does it compare? 2015. www.eiu.com/public/ topical_report.aspx?campaignid=NHScomparison2015.

3 Commonwealth Fund. Mirror, mirror, on the wall-how the performance of the US healthcare system compares internationally. 2014. www.commonwealthfund.org/ /media/ files/publications/fund-report/2014/jun/1755_davis_mirror_mirror_2014.pdf.

4 HM Treasury. A country that lives within its means: spending review 2015. Jul 2015. www. gov.uk/government/uploads/system/uploads/attachment_data/file/447101/a_country_ that_lives_within_its_means.pdf.

5 HC Powerhouse. Euro Health Consumer Index 2015. 26 Jan 2016. www. healthpowerhouse.com/files/EHCI 2015/EHCl 2015 report.pdf.

6 Riley A. Health care check-up: whose system is least efficient? Bloomberg 2015 Nov 30 www.bloomberg.com/news/articles/2015-11-30/health-care-check-up-whose-system-isleast-efficient-.

7 Niemietz K. The envy of the world? A closer look at the Commonwealth Fund healthcare study. Institute for Economic Affairs. 25 Jun 2014. www.iea.org.uk/blog/the-envy-of-theworld-a-closer-look-at-the-commonwealth-fund-healthcare-study.

8 Cylus J, Nolte E, Figueras J, McKee M. What, if anything, does the Euro Health Consume Index actually tell us? BMJ Blogs $2016 \mathrm{Feb} 9$. http://blogs.bmj.com/bmj/2016/02/09/whatif-anything-does-the-eurohealth-consumer-index-actually-tell-us/.

9 King's Fund. Healthcare spending compared to other countries. Jan 2016. www.kingsfund. org.uk/projects/nhs-in-a-nutshell/health-care-spending-compared.

10 Appleby J, Galea J, Murray R. The NHS productivity challenge: experience from the front line. King's Fund. 2014. www.kingsfund.org.uk/sites/files/kf/field/field_publication file/thenhs-productivity-challenge-kingsfund-may14.pdf.

Published by the BMJ Publishing Group Limited. For permission to use (where not already granted under a licence) please go to http://group.bmj.com/group/rights-licensing/ permissions 